\title{
Current Situation of Public Private Partnership Development for the Elderly in China
}

\author{
Xinhua Zheng1, Kun Lu', Biqiong Yan², Mengyun Li1 \\ ${ }^{1}$ School of Civil Engineering, Hefei University of Technology, Hefei, China \\ ${ }^{2}$ Anhui Tendering Group Co. Ltd., Anhui, China \\ Email:15255173427@163.com
}

How to cite this paper: Zheng, X. H., Lu, K., Yan, B. Q., \& Li, M. Y. (2020). Current Situation of Public Private Partnership Development for the Elderly in China. Open Journal of Social Sciences, 8, 165-179. https://doi.org/10.4236/jss.2020.83015

Received: February 20, 2020

Accepted: March 10, 2020

Published: March 13, 2020

Copyright $\odot 2020$ by author(s) and Scientific Research Publishing Inc. This work is licensed under the Creative Commons Attribution International License (CC BY 4.0).

http://creativecommons.org/licenses/by/4.0/

\section{(c) (i) Open Access}

\begin{abstract}
Chinese government is trying to use the Public-Private Partnership (PPP) to help the development of China's elderly care industry. This article will analyze the characteristics of pension PPP projects, summarize the current status of China's pension PPP projects and existing problems, and make some suggestions for these problems. Firstly, the article reviews the literature of China's pension PPP projects, then introduces the common types of pension PPPs, and analyzes 107 pension service projects in the project management library of the Ministry of Finance's PPP Center. Finally, it proposes the problems of existing PPP projects, and made some suggestions. The results of this study describe the current status of pension PPPs in China and provide useful references for future research.
\end{abstract}

\section{Keywords}

Public Private Partnership, Old People, China, Current Situation, Barriers, Construction Projects

\section{Introduction}

In 1999, China has entered an aging society and became the country with the largest number of elderly people in the world. The aging rate even exceeded that of many developed countries. As shown in Table 1, the number of elderly people in China is rising. As of the end of 2018, China's population aged 65 and over was 166.58 million, accounting for $11.9 \%$ of the total population (National Economic and Social Development Statistical Bulletin, 2018). In order to solve the increasingly serious problem of aging, the $65^{\text {th }}$ chapter of the " $13^{\text {th }}$ Five-Year Plan" (2016-2020) of the National "Actively Coping with Population Aging" clearly states that: improve the elderly care system, establish a home-based 
Table 1 . The elderly population in some years in China.

\begin{tabular}{|c|c|c|c|c|c|}
\hline \multirow{2}{*}{ Year } & \multirow{2}{*}{$\begin{array}{l}\text { Total population } \\
\quad(10,000)\end{array}$} & \multicolumn{2}{|c|}{ Population aged 60 and over } & \multicolumn{2}{|c|}{ Population aged 65 and over } \\
\hline & & $(10,000)$ & Percent (\%) & $(10,000)$ & Percent (\%) \\
\hline 1953 & 54,745 & 4154 & 7.32 & 2504 & 4.41 \\
\hline 1964 & 69,458 & 4225 & 6.08 & 2458 & 3.53 \\
\hline 1982 & 100,391 & 7664 & 7.63 & 4927 & 4.91 \\
\hline 1990 & 113,051 & 9697 & 8.58 & 6299 & 5.57 \\
\hline 2000 & 126,583 & 13,012 & 10.3 & 8837 & 7 \\
\hline 2008 & 132,802 & 15,989 & 12 & 10,956 & 8.3 \\
\hline 2015 & 137,462 & 22,200 & 16.1 & 14,386 & 10.5 \\
\hline 2016 & 138,271 & 23,086 & 16.7 & 15,003 & 10.8 \\
\hline 2017 & 139,008 & 24,090 & 17.3 & 15,831 & 11.4 \\
\hline 2018 & 139,538 & 24,949 & 17.9 & 16,658 & 11.9 \\
\hline
\end{tabular}

Source: Statistical bulletin on national economic and social development.

multi-level pension service system that is supported and supported by institutions. However, China's long-term family planning policy has changed the population structure and formed the current "four-two-one" family structure which is a pyramid-shaped family composed of four grandfathers, grandmothers, grandfathers, grandmothers, fathers, mothers, and an only child. So, China's Traditional family-style pensions are in trouble. Community and institutional nursing homes have become suitable alternatives to home-based nursing homes. However, the existing community and institutional nursing homes in China cannot meet the rapidly expanding needs of the elderly. The number of nursing homes in many areas and the local elderly population is in short supply. However, due to imbalances in regional development, the number of nursing homes, and the shortage of supply for the elderly in the region, and the shortcomings of existing institutions such as inherently high costs and remote locations, the existing institutional pension services in China cannot meet the rapidly expanding market demand for the pension industry. Public-Private Partnership (PPP) provides a good opportunity for the development of China's pension service industry. By introducing social capital, the government finance does not need to spend a large amount of money to build pension service infrastructure, and many economically underdeveloped areas, especially those with severe aging, can use this approach to build elderly care facilities. In addition, social capital has advantages in engineering construction and operation, so the pension PPP model can improve the efficiency of the supply of pension services.

As of December 2019, the "National PPP Integrated Information Platform Project Library" of the PPP Center of the Ministry of Finance released the third quarterly report, with a total of 9249 management library projects with an investment of 9.2 trillion yuan. There are 19 first-level industries in the management database. The top three industries are municipal engineering, transporta- 
tion and ecological construction, and the environment. The number of aged care services is only $15^{\text {th }}$. Among them, 107 aged care projects were put into storage, with an investment of 72.9 billion yuan, which accounted for $1 \%$ of the total number of stored items and $0.5 \%$ of total investment. It can be seen that the development of PPP projects for senior care services is not optimistic. On the one hand, due to the shortcomings of the PPP model, on the other hand, PPP model in aged care services is in the early stage of development, and there are few successful cases. Therefore, there are a series of problems. This article will use text analysis to explore the implementation of pension PPP projects obstacle.

However, there are many obstacles to China's pension PPP projects, and current research lacks a description of them. Therefore, this article reviews the status quo and development obstacles of China's pension PPP project, hoping that it will help to some extent. The framework of this paper is as follows: Section 2 reviews the literature of China's pension PPP; Section 3 analyzes the existing pension PPP projects of the Ministry of Finance PPP project library; Section 4 analyzes the main problems existing in China's pension PPP project and puts forward some suggestions; Section 5 is the conclusion paragraph and summarizes the article.

\section{Literature Review}

The PPP model originated in the United Kingdom (Delorme, Thompson, \& Warren, 1999), and it includes three aspects of meaning: first, the trend of privatization of public sector activities; second, contract financing of private financing and taking risks; third, selling government services through public-private partnership agreements (Spackman, 2002). According to the United Nations Development Program, PPP refers to the form of mutual cooperation between the government, for-profit enterprises and non-profit organizations based on a project. Through this form of cooperation, the parties to the cooperation can achieve more favorable results than expected by acting alone (Jiang, Lu, Xia, Liu, \& Cui, 2019). So it has attracted extensive attention from the public sector and has been adopted in more and more countries (World Bank, 2019).

Through this form of cooperation, the parties to the cooperation can achieve more favorable results than expected by acting alone. When participating parties participate in a project, the government does not transfer all the responsibility of the project to the private sector, but the participating parties share the responsibility and financing risks (Liu, 2015). In addition, Chinese scholars still have ambiguity in the definition of PPP. Former Minister of Finance Lou Jiwei pointed out: Broad PPP refers to the cooperative relationship established between the government and the private sector to provide public goods or services. It is characterized by the authorization of franchise and mainly includes BOT, BOO, PFI and other models. The principle of narrow PPP is similar to that of BOT, both of which are paid by users, but it emphasizes the entire process of public sector cooperation more than BOT (Liu, 2015). As the PPP model places 
more emphasis on cooperation, it is said that PPP is a long-term partnership established through formal agreements between the public and private sectors in infrastructure (Lian, 2011). Chen Zhe believes that PPP is a way for enterprises to obtain government franchise rights and provide infrastructure and public utility construction and services traditionally responsible by the government (Cheng \& Wang, 2011).

Regarding the application of the pension PPP model in the pension industry, as early as the 1970s, there are many scholars in the world discussing the intervention of pension service marketization. David Shulman proposes the use of government-funded construction and business operations to improve the supply of senior care services (Shulman \& Galanter, 1976). Dan M explores how the government manages the investment and financing of the pension industry, and puts forward market-oriented proposals for funding sources for pension projects (McGill, 1988). Regarding the research on pension methods, the related research focuses on pension insurance. Taking An Chen as an example, the research results show that the fixed income plan for the elderly in the United States after retirement is guaranteed by a welfare guarantee company, by establishing a valuation risk model of the endowment insurance to simulate the endowment insurance of the guarantee company, and guaranteed by the occupational pension plan Basic benefits of retirees (Chen, 2011). Pension funds are also a means of pension. Investing pension funds in real estate has lower costs and higher returns (Andonov, 2015). At present, the mature industry market in developed countries has formed a mature market-oriented model. In contrast, the PPP model is still in its infancy in China.

Hao Tao and others believe that the PPP model docking with the elderly service industry can play a role in complementing each other and balancing each other, and can solve the problem of insufficient total supply and unreasonable structure in the supply of elderly services (Hao et al., 2018). Applying the PPP model in the construction of pension institutions can not only effectively alleviate the government's financial investment pressure, but can also solve the problem of insufficient supply of pension institutions and low operating efficiency to a certain extent (Carbonara et al., 2014; Guan, 2013). In addition, the elderly PPP model should follow objective laws. From theory to practice, from documents to specific operations, it is necessary to understand the changing trend of the aging of the population, grasp the operating law of the elderly industry, and continuously strengthen the management of the operational cooperation implementation process $(\mathrm{Mu}, 2015)$. However, the development of the pension PPP model in China has encountered many problems, such as the inadequate supervision in the later stage, no supporting laws and regulations, and the current administrative supervision is difficult to achieve "win-win", so the government needs to strengthen supervision and improve supervision legislation (Han \& Chen, 2018).

The theoretical research on pension PPP projects mainly focuses on risk 
sharing and income distribution. The key to the success of a pension PPP project depends on the design of the risk sharing mechanism. The public and private parties should negotiate the PPP on the principle of PPP risk sharing, so that the setting of risk sharing can be accepted by both parties and then clarified by the PPP contract. Parties' responsibilities, rights and obligations (Song, 2004). In addition, solving the problem of reciprocity of risks and benefits, and analyzing the distribution of the benefits of different models is also important for pension PPP projects (Jia \& Xu, 2014). But there are few studies on obstacles in the process of the project. Gao Zhen et al. Summarized the four dilemmas of the PPP pension project in Shandong Province, with insufficient participation of social forces; limited financing channels and a single source of funds; lack of professional elderly service talents; lack of industry standards and supervision (Gao et al., 2018). This article will explore the obstacles in the implementation of pension PPP projects based on the characteristics of the existing pension PPP projects nationwide, combined with literature analysis.

\section{Research Methods}

This article focuses on the elderly PPP project in the Ministry of Finance's PPP project library as the main research object. The time of the research project is from 2014 to 2019. Based on the analysis of the related characteristics of pension PPP projects, the current development status and existing problems of domestic pension PPP projects are summarized. Regarding data processing, this article mainly uses Excel and SPSS.

\section{Statistical Analysis of PPP Projects}

In 2014, in order to adapt to the rapid development of China's new urbanization strategy, the ministry of finance launched the public-private partnership for infrastructure construction. After that, the State Council issued a document to promote the PPP model in all public service areas to provide public services.

In order to better manage PPP projects, the Ministry of Finance established the Government and Social Capital Cooperation Center in 2014. For PPP projects that meet relevant requirements, they are included in the Ministry of Finance PPP project database, which is divided into project management database and project reserve list, project management database Refers to projects in the preparation, procurement, implementation, and handover stages, which have completed the evaluation of value for money and financial affordability demonstration. The project reserve list refers to the identification phase of the project. It is an alternative project where the local government department is willing to adopt the PPP model, but has not yet completed the review of the value for money evaluation and demonstration of financial affordability, and it is still a long time before the project landed. Based on the project management database of the Ministry of Finance PPP Center, a PPP pension project database has been established, which includes the project name, implementation stage, investment amount, 
launch time, planned cooperation period, return mechanism, operation mode, and social capital. The project information is as of 2019 December. Descriptive and statistical analysis of the above data shows the main characteristics of China's pension PPP project.

This article collected information on 107 elderly care services in the project management database of the Ministry of Finance's PPP Center. As all the items in the reserve list are in the identification stage, they have not completed the review of the value for money evaluation and the demonstration of financial affordability, and they have left the project Still a long time (Project Management Library of the Ministry of Finance PPP Center). In addition, in 2017, the Ministry of Finance issued a series of documents, such as Document 92, which required separate management of projects in the project management database and those in the reserve list at the identification stage, and in all subsequent quarterly reports issued only for projects Statistics and analysis of items in the management library. Therefore, the elderly care service items in the reserve list are outside the scope of this study.

\subsection{The Launch Time of Project}

The old-age pension PPP projects that were put into the library were first launched in 2012. As shown in Figure 1, due to the influence of national policies, the number of old-age pension PPP projects gradually increased from 4 (2014) to 37 (2016) and then began to drop to 2 (2019). This law shows that in the early stage of the development of PPP projects, affected by policy dividends, various regions across the country have initiated pension PPP projects. Due to Document 92 issued by the Ministry of Finance in 2017 and other reasons, a large number of PPP projects have been withdrawn from the project library, and many have to be entered The projects in the library cannot be stored because they cannot meet the corresponding requirements. Therefore, the number of pension PPP projects initiated is gradually decreasing since 2017.

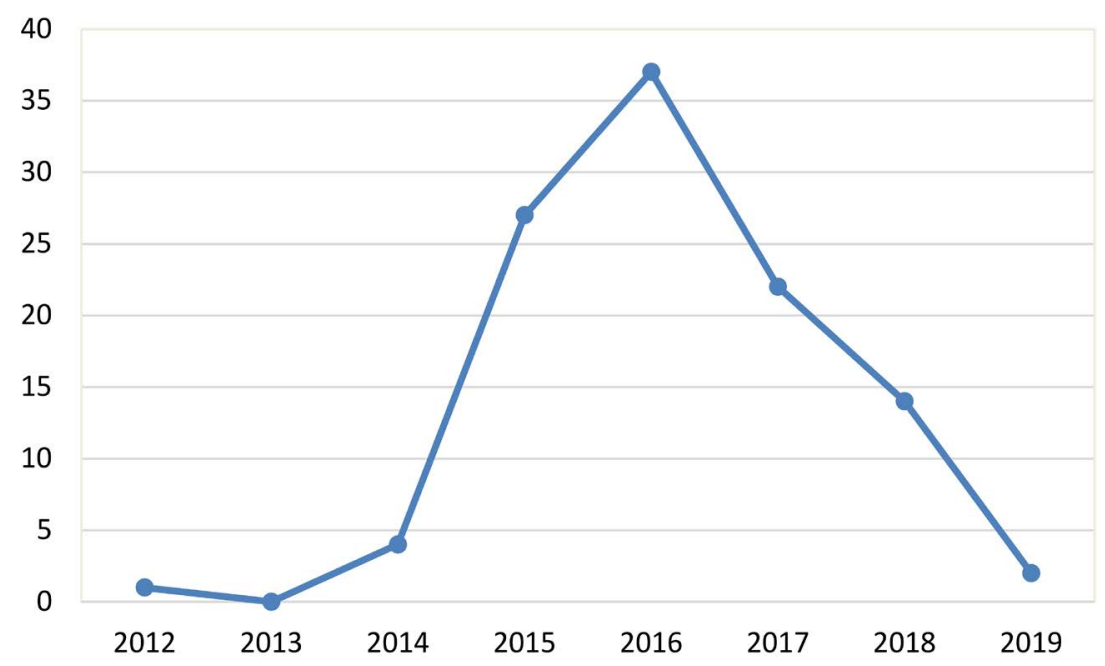

Figure 1. The launch time of project. 


\subsection{Main Categories of Projects}

The main types of pension projects in China currently include pension apartments, home-based pensions, community-based pensions, integrated medical care, ecological pensions, smart pensions, these types of pension models shown in Table 2.

There are 54 old-age care projects in the library that are integrated with medical care, accounting for $49 \%$ of the total, with an average investment of 820 million yuan; elderly apartments (8), accounting for $7 \%$, with an average investment of 899 million yuan; comprehensive types of old-age care projects (45), including welfare centers, ecological pensions, community pensions, and industrial pensions, accounting for $42 \%$, with an average investment of 478 million yuan. The results show in Figure 1 and Figure 2. In terms of regional distribution,

Table 2. Feature of pension models.

\begin{tabular}{llll}
\hline Pension model & Function & Main service object & Features \\
\hline $\begin{array}{l}\text { Pension } \\
\text { apartment }\end{array}$ & $\begin{array}{l}\text { Apartments } \\
\text { available }\end{array}$ & $\begin{array}{l}\text { Older people with better } \\
\text { economic conditions }\end{array}$ & $\begin{array}{l}\text { Market-oriented senior } \\
\text { housing }\end{array}$ \\
Home care & $\begin{array}{l}\text { Provide social } \\
\text { services }\end{array}$ & $\begin{array}{l}\text { Older people with average } \\
\text { economic conditions }\end{array}$ & $\begin{array}{l}\text { Various types of service } \\
\text { agencies cooperate to provide }\end{array}$ \\
nursing home & $\begin{array}{l}\text { Provide convenient } \\
\text { services during the } \\
\text { day }\end{array}$ & $\begin{array}{l}\text { Elderly people left } \\
\text { unattended during the day }\end{array}$ & $\begin{array}{l}\text { Small investment, small scale, } \\
\text { small footprint }\end{array}$ \\
$\begin{array}{l}\text { Integration of } \\
\text { medical care }\end{array}$ & $\begin{array}{l}\text { Elderly Services and } \\
\text { Medical Services }\end{array}$ & $\begin{array}{l}\text { Senior population with high } \\
\text { demand for healthcare }\end{array}$ & $\begin{array}{l}\text { Responsible subjects include } \\
\text { families and institutions }\end{array}$ \\
$\begin{array}{l}\text { Ecological } \\
\text { pension }\end{array}$ & $\begin{array}{l}\text { A new pension } \\
\text { model close to the } \\
\text { ecological }\end{array}$ & $\begin{array}{l}\text { Older people seeking to be } \\
\text { close to the natural } \\
\text { environment }\end{array}$ & $\begin{array}{l}\text { Conducive to the } \\
\text { construction of ecological }\end{array}$ \\
$\begin{array}{l}\text { Smart retirement } \\
\text { Provide highly } \\
\text { intelligent elderly } \\
\text { care services }\end{array}$ & $\begin{array}{l}\text { Older people who want to } \\
\text { meet more and better } \\
\text { material and cultural needs }\end{array}$ & $\begin{array}{l}\text { combining information } \\
\text { technology and intelligence }\end{array}$ \\
\hline
\end{tabular}

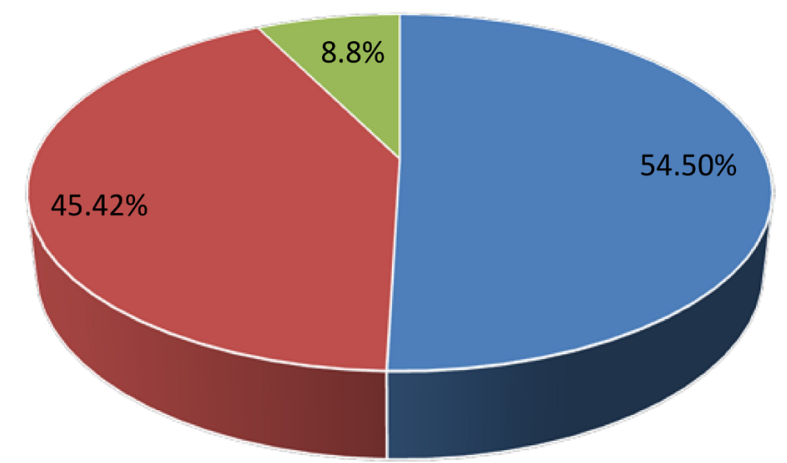

- old-age care integrated with medical care

- comprehensive types of old-age care

- elderly apartments

Figure 2. The types of old-age care project. 


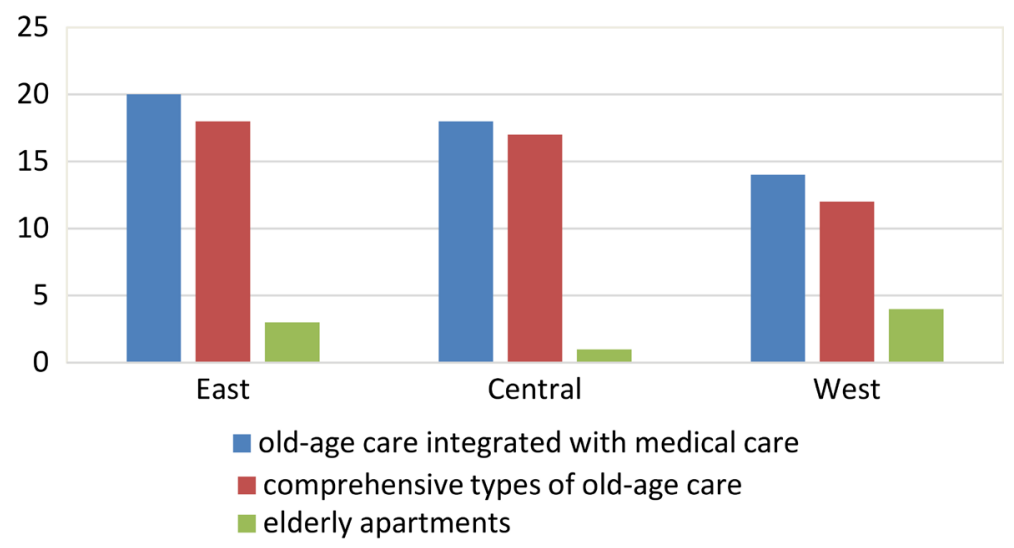

Figure 3. The types of old-age care project in China.

$50 \%$ of the projects in the east choose a combination of medical care and elderly care, with a total of 18 pensions and 3 elderly apartments. At this stage, the biggest demand of China's aged care market is to be able to obtain basic and middle-end aged care service PPP projects of high-quality and perfect home community aged care services, so that most elderly people can get more intimate and thoughtful services. And social capital has less investment in basic security and mid-range projects, and it prefers to invest in high-end elderly care projects, such as medical care, elderly apartments, and ecological nursing homes.

\subsection{The Area Distribution of Project}

In terms of regional distribution, there are 42 elderly pension PPP projects in the east, accounting for $39 \%$ of the total; the middle (36), accounting for $35 \%$, and 2 the west (25), accounting for $26 \%$. The results show in Figure 3. It is not difficult to see that the advantages of the eastern region are its strong economic foundation and relatively sufficient financial resources. With regard to the provision of old-age care services, the main old-age care models in the eastern region are supplemented by government-led old-age care institutions and private nutrition old-age institutions. With the increasing aging of the population, the demand for pension institutions has also increased significantly. In addition, with the abundant social capital resources in the eastern region, the elderly have great potential for consumption. Therefore, the development of pension PPP projects in the eastern region nationwide more advantages. In terms of regional distribution of pension PPP projects, the top three provinces are Shandong, Henan, and Jiangsu, results show in Figure 4. Taking Henan Province, a national PPP project pilot area, as an example, the elderly population dependency ratio in the province was as high as 15.88 in 2017 . The size of the elderly population is huge and growing rapidly, and the contradiction in elderly care services is increasingly prominent (Yang \& Cui, 2019). In addition, the province's fiscal deficit in 2017 was the highest, reaching 482.679 billion yuan, and the local financial burden was heavy. Therefore, the introduction of private capital into the elderly care industry has become the first choice. It is not difficult to explain that Henan 
Province has the largest number of PPP projects for the elderly in the country.

\subsection{The Investment Scale Project}

There are 19 projects with a total investment scale of more than 1 billion yuan, accounting for $18 \%$ of the total, with an total investment of 44.8 billion yuan, accounting for $61 \%$ of the total investment. And from 300 million to 1 billion yuan (42), accounting for $39 \%$, from 100 million to 300 million yuan (33), accounting for $31 \%$. There are 13 scales below 100 million yuan, accounting for $12 \%$. Results show in Figure 5. Secondly, in terms of regional distribution, the average investment in the eastern region was 958 million yuan, followed by the central region with 608 million yuan and the western region with 425 million yuan. Pension PPP projects with an investment scale of over 1 billion yuan exceed $61 \%$, which is a type of infrastructure project with a large investment amount. In addition, the average investment amount in the eastern region is significantly higher than other regions. Large population density places high demands on the scale of old-age facilities.

Projects
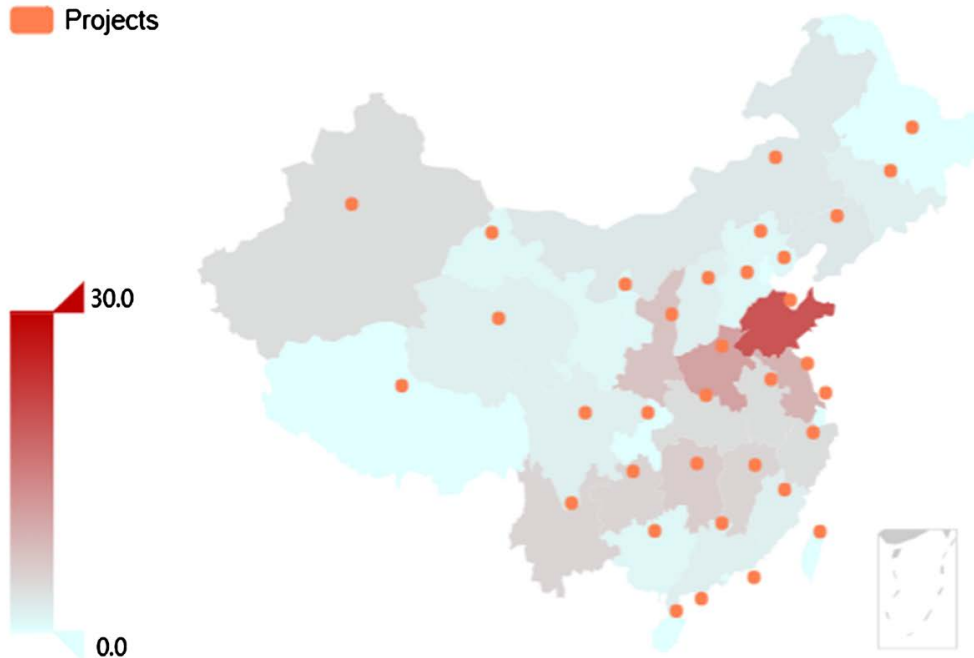

0.0

Figure 4. Area distribution map of projects.

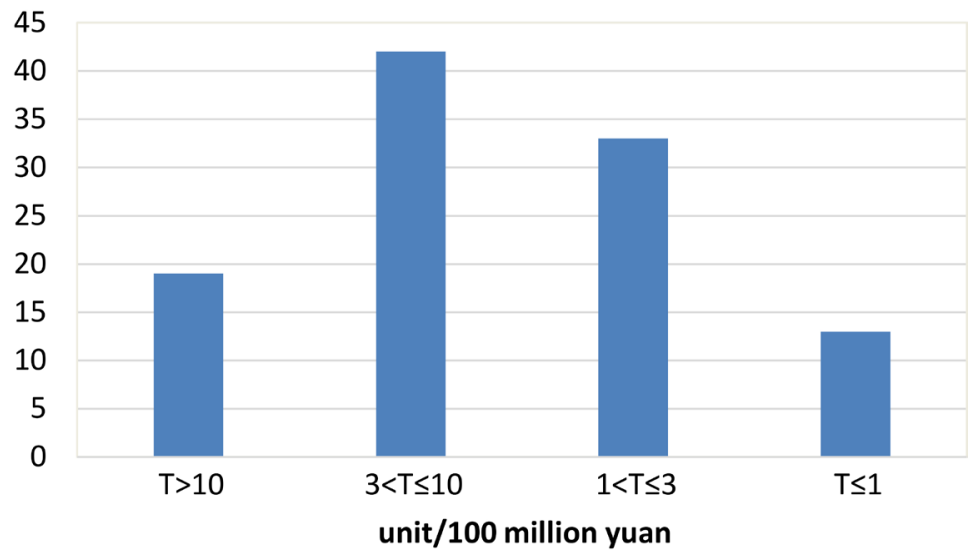

Figure 5. Investment scale project of projects. 


\subsection{The Implementation Progress of Project}

According to the Ministry of Finance standards, the project completion rate refers to the ratio of the sum of the number of projects in the two stages of execution and transfer to the sum of the number of projects in the four stages of preparation, procurement, execution and transfer. Based on this calculation, the implementation rate of the aged care projects in the library is $60 \%$. In addition, as shown in Figure 6, 24 have entered the procurement stage, execution (64), preparation (19), transfer (0). In terms of regional distribution, the landing rate is $67 \%$ in the east, the middle (61\%), and the west (56\%). Judging from the landing rate, there is not much difference in various regions of the country. On the one hand, the Ministry of Finance has strengthened the review of inbound projects and strictly controlled the entry and exit of the projects. In addition, the regional governments have strengthened the management of pension PPP projects from project establishment, construction, and operation.

\subsection{The Operation Method, Return Mechanism and Cooperation Period of Projects}

Among the operation modes adopted by the project, there are BOT (Build-Operation-Transfer) (56), accounting for 52\% of the total; and BOO (Build-OwnOperation) (32), accounting for 30\%; ROT (Rent-Operation-Transfer) (4), accounting for $4 \%$; TOT (Transfer-Operation-Transfer) (2), accounting for $2 \%$; TOT + BOT (1) and TOT + BOO (1), each accounting for $1 \%$ of the total, and the other (11), Accounting for 10\%. Results show in Figure 7. In the project return mechanism, There are users paid (44), accounting for $41 \%$, and the average duration of the proposed cooperation was 25.8 years; the feasible gap subsidies (62), accounting for $58 \%$, and the average planned duration of cooperation was 23.1 years; The government paid (1) accounting for $1 \%$, The proposed cooperation period is 10 years. Results show in Figure 8 . The main payment types are user payment and feasibility gap subsidy, accounting for $99 \%$ in total. Pension PPP projects belong to a category of projects with low self-payment rates, and it is difficult to attract social capital investment according to them. Due to China's long-term urban-rural dual structure imbalance and imperfect pension system, the overall ability to pay off the elderly in China is weak (Yang \& Cui, 2019).

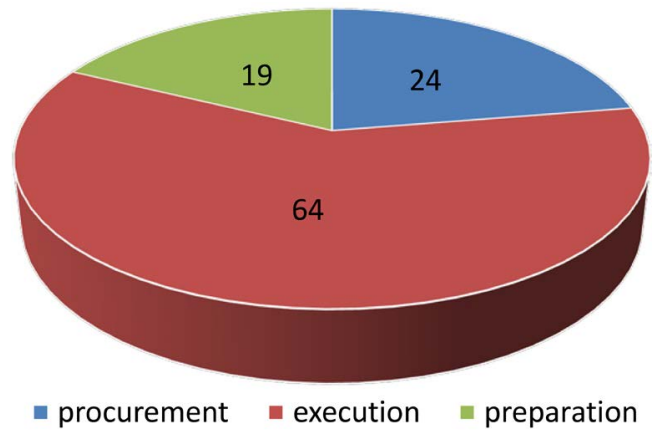

Figure 6. Implementation progress of project. 


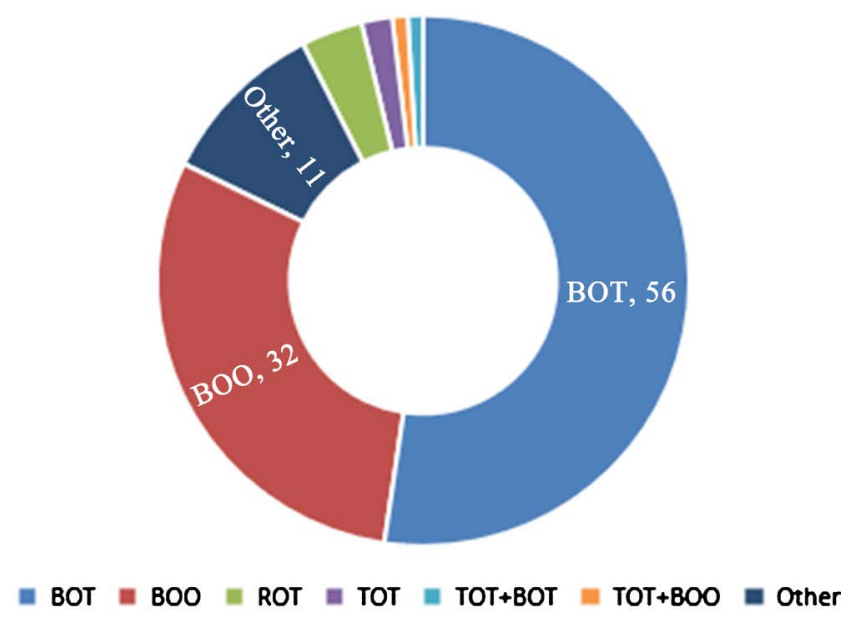

Figure 7. Operation method of project.

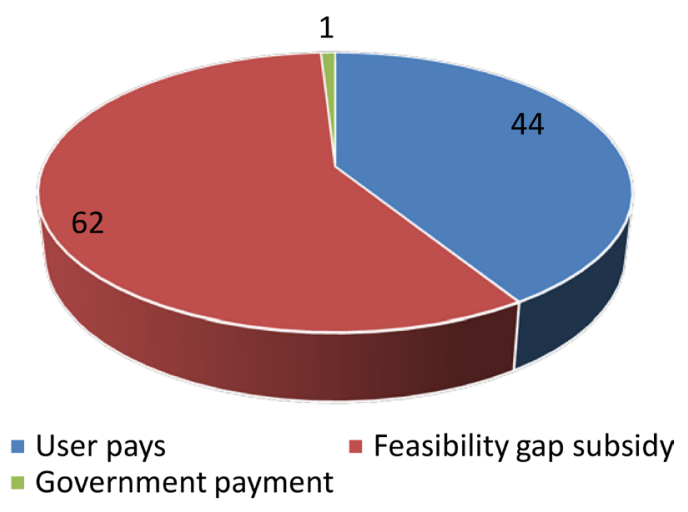

Figure 8. Return mechanism of project.

Therefore, it is difficult to attract social capital to invest solely through user payment models or feasibility gap subsidies.

\subsection{Summary}

Through the analysis of the project's launch time, regional distribution, investment scale, implementation progress, operation mode, return mechanism, and cooperation period, we can see that there is a mismatch in the existing model choices, imbalanced development among regions, inadequate payment models and large investment, long payback period and other issues in China's pension PPP projects. At the same time, since the Ministry of Finance issued Document 92 in 2017, the number of newly launched PPP projects has gradually decreased, but the overall implementation rate of the projects is relatively high. On the one hand, it is related to the strengthening of policies and policies, and on the other hand, local governments prudently initiate PPP project.

\section{Existing Problems in PPP Projects}

\subsection{Mismatch in Pension PPP Project Model Selection}

According to the results of the above data analysis, it can be seen that the elderly 
care projects of the high-end elderly care model such as the combination of medical care and ecological care account for the majority. On the one hand, it shows that this type of project is more favored by social capital, and secondly, this type of project is relatively smooth. But at this stage, the demand of China's elderly care service market is concentrated on basic guarantees that can provide high-quality services and mid-end elderly PPP projects, such as home-based community elderly care service projects and mid-end medical and nursing integration projects. However, the investment direction of social capital tends to be high-end elderly apartments, ecological pensions and other high-quality, high-end premium pension services. People still do not have access to appropriate care for the elderly. It is not difficult to find that PPP projects have public welfare characteristics. Obviously, for-profit pension projects are not suitable for PPP mode. In the choice of the model, factors such as the needs of the local pension market and the spending power of the elderly need to be comprehensively considered.

\subsection{Unbalanced Regional Development of Pension PPP Projects}

From the analysis of the location of the pension PPP projects in the region above, the number of pension PPP projects in Shandong and Henan is in a leading position. The number of pension PPP projects in other densely populated areas such as Beijing, Shanghai, and Shenzhen is very small, and some regions do not even have. Secondly, Shandong and Henan belong to large population provinces, which have also created a large demand for elderly care services. However, this rule is not absolute. For example, Guangdong Province in the east has the largest population in the country. However, the pension institutions and private pension institutions operated and operated by the government's economically developed governments have been able to meet basic pension needs. For areas using the PPP model, areas where pension PPP projects develop well, with their rich management experience, attract more social capital to invest, resulting in uneven development between regions, and this phenomenon will become more and more serious in the long run.

\subsection{Unreasonable Choice of Payment Model for Pension PPP Project}

Most of the pension PPP projects adopt the user payment model, and social capital is responsible for their own profits and losses. However, at present, China's pension PPP project is still in the initial exploration stage. There are many uncertain factors in the PPP project itself: various forms, complex charging standards, huge price elasticity, and lack of mature system experience; high requirements for soft services and high operating costs; Insufficient policy subsidies, the elderly's ability to pay as a whole are weak, and the cycle of fund recovery is long. In addition, pension service PPP projects cannot be compared with PPP mode projects such as high-speed railways, waste incineration, and sewage treat- 
ment, and clear indicators can be used to measure the eligibility of the projects. In addition, the current evaluation standards for old-age care projects are more focused on the evaluation of hardware facilities, and there is no relatively complete and complete standard for evaluation of soft services. Therefore, a reasonable payment model is a prerequisite to ensure the smooth implementation of the pension PPP project.

\subsection{Pension PPP Projects Have Large Investment Amounts and Long Payback Periods}

Pension PPP projects have large upfront investment, relatively low returns, and long payback periods. According to the analysis of the pension projects in the project management database above, the main operating models of pension PPP projects are $\mathrm{BOT}$ and $\mathrm{BOO}$. These two models require a large amount of investment in the early stage. In addition, pension service projects are of a certain public interest nature. According to the main indicators for the development of the country's old-age cause and the construction of the pension system during the "Thirteenth Five-Year Plan" period, the proportion of government-run pension beds must not exceed $50 \%$, and the proportion of nursing-type pension beds must not be less than $30 \%$. With sufficient space for intervention, it is hoped that social forces will ultimately bear the main responsibility for the provision of elderly care services. However, the government prematurely required social capital to bear the main risks, resulting in the lack of confidence of private forces in the ability of pension-type PPP projects to generate income, and they dared not enter rashly.

\section{Conclusion}

Through a systematic analysis of the pension PPP projects in the library, we can see that China's preliminary exploration of the pension PPP model has achieved certain results, but due to the complexity of the entire operation process, many problems need to be resolved. The four major issues summarized in this article can provide a reference for government departments and social capital in constructing PPP projects for the elderly service industry, and can also provide clues for industry experts to explore obstacles in the elderly service industry.

According to the analysis of the types, originating areas, investment amounts, implementation models, and return methods of pension PPP projects, it can be seen that the choice of pension PPP project types should be based on the economic, cultural, and environmental factors of the region. The region's economic situation or degree of aging, the introduction of appropriate pension PPP projects, such as Guizhou, Inner Mongolia and other economically underdeveloped areas, in the choice of pension type, should focus on the pension industry, such as home pension, community pension and other low-end pension services. On the one hand, the elderly's needs in these areas are still in the basic aspects of basic living care, which is closely related to their spending power. On the contrary, for 
coastal areas or economically developed areas, the construction of high-end senior care institutions, or even high-end senior care institutions, should be encouraged. Secondly, in the choice of cooperation mode, try to choose a model that is conducive to the smooth supply of pension services. Innovative cooperation modes can be implemented. For example, by cooperating with specific projects, some of the professional services of pension services, such as medical services, can be provided with professional services. Cooperation with medical institutions; also through the service outsourcing model, some of the less important services can be packaged as a whole to a third party, such as simple tasks such as cleaning and security. Of course, this puts forward higher requirements for the management of PPP project companies. Finally, in terms of the choice of return methods, the government prefers the user payment model, which can effectively reduce the pressure on local fiscal expenditure. However, due to the public welfare characteristics of pension projects, many pension projects cannot maintain the normal operation of the project company through user payments, which requires the government to provide subsidies in the early stage or even the entire process.

To sum up, China's pension PPP project is still in its infancy, such as imbalance between supply and demand, unreasonable choice of payment model, and large investment amount, which requires the participation of many participants to solve. At the same time, the public sector should abide by the spirit of the contract and perform the contracted responsibilities on time; the social capital side should have a sense of social responsibility and should not pay too much attention to the project's early income in order to ensure the smooth progress of the project.

\section{Conflicts of Interest}

The authors declare no conflicts of interest regarding the publication of this paper.

\section{References}

Andonov, A. (2015). Intermediated Investment Management in Private Markets: Evidence from Pension Fund Investments in Real Estate. Journal of Financial Markets, 22, 73-103. https://doi.org/10.1016/j.finmar.2014.11.002

Carbonara, N., Costantino, N., \& Pellegrino, R. (2014). Concession Period for PPPs: A Win-Win Model for a Fair Risk Sharing. International Journal of Project Management, 32, 1223-1232. https://doi.org/10.1016/j.ijproman.2014.01.007

Chen, A. (2011). A Risk-Based Model for the Valuation of Pension Insurance. Insurance: Mathematics and Economics, 49, 401-409. https://doi.org/10.1016/j.insmatheco.2011.06.002

Cheng, Z., \& Wang, S. Q. (2011). Designing the Framework of Public-Private Partnership Financing Projects for Nonprofit Hospitals. Chinese Health Service Management, 28, 557-559.

Delorme, C. D., Thompson, H. G., \& Warren, R. S. (1999). Public Infrastructure and Private Productivity: A Stochastic-Frontier Approach. Journal of Macroeconomics, 21, 
563-576. https://doi.org/10.1016/S0164-0704(99)00116-0

Gao, Z., Yu, K. L., \& Chen, Z. (2018). Analysis on the Development Dilemma and Path of PPP Pension Project Construction in Shandong Province. Labor Security World, No. 29, 26-27.

Guan, X. (2013). Research on the Application of Model in Construction of Pension Institutions. Dalian: Dongbei University of Finance and Economics.

Han, X. P., \& Chen, M. (2018). Problems and Countermeasures of China's Pension Industry PPP Project Operation. Economic Review Journal, No. 4, 81-86.

Hao, T., Shang, Q., \& Li, J. (2018). Research on the Effective Supply Path of Integrated Medical Care and Pension Services under PPP Mode. Macroeconomics, No. 11, 44-53.

Jia, L., \& Xu, Z. Y. (2014). Analysis of Risks and Benefits of Promoting the Application of PPP Model in the Pension Service. Science Technology and Industry, 14, 57-61+140.

Jiang, X., Lu, K., Xia, B., Liu, Y., \& Cui, C. (2019). Identifying Significant Risks and Analyzing Risk Relationship for Construction PPP Projects in China Using Integrated FISM-MICMAC Approach. Sustainability, 11, 5206. https://doi.org/10.3390/su11195206

Lian, H., J. (2011). Empirical Research on the Relationship between SMEs' Participation in PPP Model and Technology Innovation. Reformation \& Strategy, 27, 155-157.

Liu, W. (2015). Explanation of the Theory of PPP Model and Its Practical Examples. Reform, No. 1,78-89.

McGill, D. M. (1988). Economic and Financial Implications of the Aging Phenomenon. Proceedings of the American Philosophical Society, 132, 154-171.

$\mathrm{Mu}, \mathrm{G}$. Z. (2015). Successful Aging: A Strategic Vision for China's Aging Governance. Journal of the Party School of the Central Committee of the C.P.C., No. 3, 55-61.

National Economic and Social Development Statistical Bulletin (2018). http://www.stats.gov.cn/tjsj/zxfb/201902/t20190228_1651265.html

Project Management Library of the Ministry of Finance PPP Center. http://www.cpppc.org:8086/pppcentral/map/toPPPList.do

Shulman, D., \& Galanter, R. (1976). Reorganizing the Nursing Home Industry: A Proposal. The Milbank Memorial Fund Quarterly. Health and Society, 54, 129-143. https://doi.org/10.2307/3349584

Song, Z. D. (2004). Risk Sharing and Contract Management in BOT Financing. Journal of Jilin Province Economic Management Cadre College, No. 1, 28-31.

Spackman, M. (2002). Public-Private Partnerships: Lessons from the British Approach. Economic Systems, 26, 283-301. https://doi.org/10.1016/S0939-3625(02)00048-1

World Bank (2019). Private Participation in Infrastructure Database.

Yang, Z., \& Cui, Z. (2019). Research on the Application and Promotion of PPP Model in the Elderly Service Field. Finance \& Economics of Xinjiang, No. 5, 38-51. 